\title{
Performa Ayam Broiler Strain Cobb yang Diberi Herbal Kunyit
}

\section{(Cobb Strain Broiler Chicken Perfomance That Given Herbal Turmeric)}

\author{
F. Akhsan ${ }^{1 *}$, Harifuddin ${ }^{1}$, dan M. Irwan ${ }^{2}$ \\ ${ }^{1}$ Program Studi Agribisnis Peternakan, Politeknik Pertanian Negeri Pangkajene Kepulauan \\ ${ }^{2}$ Program Studi Peternakan, Universitas Muhammadiyah Sidenreng Rappang \\ *Penulis Korespondensi email: fitriana.akhsan@yahoo.com
}

\begin{abstract}
ABSTRAK
Penelitian ini bertujuan untuk performa ayam broiler yang diberi herbal kunyit dengan pemberian melalui pakan dan air minum. Ayam yang digunakan adalah DOC strain Cobb sebanyak 96 ekor. Penelitian menggunakan rancangan acak lengkap dengan 3 perlakuan dan 4 ulangan. Susunan perlakuan yaitu : $\mathrm{T}_{0}=$ Pakan basal, $\mathrm{T}_{1}=$ Pakan basal +2 $\%$ kunyit dari jumlah konsumsi pakan dan $\mathrm{T}_{2}=$ Pakan basal $+2 \%$ kunyit dari jumlah konsumsi air minum. Parameter yang diamati yaitu performa ayam broiler yang terdiri dari konsumsi pakan, konsumsi air minum, pertambahan bobot badan, bobot badan akhir, konversi pakan, mortalitas dan Income over feed and chick cost. Konsumsi pakan, konsumsi air minum, pertambahan bobot badan, bobot badan akhir, konversi pakan dan mortalitas tidak dipengaruhi oleh perlakuan secara nyata $(\mathrm{P}>0,05)$. Income over feed and chick cost tertinggi pada perlakuan T2 yaitu Rp 11.582,-. Kesimpulan dari peneltian ini adalah pemberian kunyit lebih optimal jika diaplikasikan melalui air minum pada taraf $2 \%$.
\end{abstract}

Kata Kunci: Performa, Ayam broiler, Kunyit, pakan, air minum

\section{ABSTRACT}

This research aimed to compare broiler chicken's performance fed turmeric herbs through feed and drinking water. A total of 96 day old chicks (DOC) strains Cobb $_{\overline{7}}$ were used in this research and distributed in. completely randomized designed with 3 treatments and 4 replicates. The treatments were the following: $T 0=$ basal feed, $T 1=$ basal feed $+2 \%$ turmeric from the amount of feed consumption and $\mathrm{T} 2=$ basal feed $+2 \%$ turmeric from the amount of drinking water consumption. The parameters observed in this study were the performance of broilers consisting of feed consumption, drinking water consumption, body weight gain, final body weight, feed conversion, mortality and income over feed and chicken costs. Feed consumption, drinking water consumption, body weight gain, final body weight, feed conversion and mortality were not affected by the treatment significantly (P> 0.05). The highest income from feed and chicken costs was in treatment T2 which is Rp. 11,582. The 
conclusion of this research was application of $2 \%$ turmeric was better through drinking water: Rather than included in the feed.

Keywords: Performance, Broiler, Turmeric, feed and water.

\section{PENDAHULUAN}

Peningkatan produksi ayam broiler berkembang sangat pesat. Kemajuan teknologi dibidang perunggasan merupakan salah satu sebab hal tersebut terjadi. Penelitian yang secara terus menerus dikembangkan berhasil menemukan teknologi aplikatif dalam meningkatkan produksi ayam broiler. Salah satu hasil penemuan tersebut yaitu penggunaan Antibiotic Growth Promoter (AGP) pemacu pertumbuhan. Ayam broiler rentan terhadap serangan penyakit sehingga perlu pemakanian AGP untuk menjaga imunitas dan pertumbuhan (Ulupi et al., 2015). AGP adalah produk yang secara luas telah digunakan oleh peternak di Indonesia. Namun demikian penggunaan AGP tersebut sayangnya menimbulkan efek negatif terhadap kesehatan konsumen. Penggunaan AGP akan menimbulkan residu antibiotik pada tubuh ayam. Apabila ayam broiler tersebut dikonsumsi maka akan menyebabkan tubuh konsumen resisten terhadap beberapa jenis bakteri dan virus. Sinurat et al. (2003) menyatakan bahwa antibiotik meninggalkan efek yang buruk, yaitu residu pada produk yang dihasilkan yang dapat menggangu kesehatan bagi yang mengkonsumsinya. Selajutnya (Castanon, 2007) menyatakan bahwa residu antibiotik dalam daging yang dihasilkan ayam broiler akan menurunkan resistensi manusia yang mengkonsumsinya terhadap beberapa jenis antibiotic. Budidaya menggunakan antibiotika meninggalkan residu pada daging ayam broiler mencapai
$27,08 \%$ dari total sampel (13 dari 48 sampel) (Marlina et al., 2015).

Kunyit merupakan salah satu tanaman herbal yang dapat dijadikan sebagai antibiotik alami. Penggunaan tanaman herbal diharapkan mampu menekan penggunaan AGP yang telah diketahui memberikan pengaruh negatif terhadap kesehatan konsumen. Kunyit mengandung kurkuminoid yang berbentuk kurkumin dan minyak atsiri. Kurkumin dapat meningkatkan kemampuan saluran cerna untuk mencerna pakan lebih efisien. Minyak atsiri pada kunyit dapat mempercepat pengosongan isi lambung (Adi, 2009) ,sehingga akan meningkatkan kapasitas pencernaan. Zat aktif kurkumin yang diberikan pada ayam broiler mempengaruhi tingkat konsumsi, pertambahan berat badan dan nilai konversi (Sutaji 2012). Sehingga, penggunaan herbal dalam pakan ayam broiler dapat menjamin kesehatan konsumen serta mempertahankan laju pertumbuhan broiler.

Kunyit dapat diberikan kepada ayam broiler melalui pakan maupun air minum. Pemberian kunyit melalui pakan dalam bentuk tepung kunyit sedangkan pemberian kunyit melalui air minum dalam bentuk cairan perasan kunyit. Kedua metode pemberian yang berbeda tentu saja akan memberikan efek yang berbeda. Oleh karena itu penelitian ini dilakukan dengan tujuan untuk mengetahui performa ayam broiler yang diberi herbal kunyit dengan pemberian melalui pakan dan air minum. 


\section{MATERI DAN METODE}

\section{Waktu dan Lokasi Penelitian}

Penelitian ini dilaksanakan selama 2 bulan. Dimulai pada bulan Juli 2019 hingga bulan Agustus 2019 di Kampus Politeknik Pertanian Negeri Pangkajene Kepulauan, Pangkep

Ternak dan Pakan Percobaan

Penelitian ini menggunakan 96 ekor Day Old Chick (DOC) Strain Cobb masingmasing 8 ekor untuk setiap unit percobaan. Kandang yang digunakan dalam penelitian ini yaitu kandang litter dengan ukuran 1 x 1,5 m. Penelitian ini dilakukan dengan menggunakan rancangan acak lengkap terdiri dari 3 perlakuan dan 4 ulangan. Pakan basal yang digunakan adalah Crumble BP 11 PT. Charoen Pokphand Indonesia. Perlakuan ransum yang digunakan adalah sebagai berikut :

$\mathrm{T}_{0} \quad$ = Pakan basal

$\mathrm{T}_{1}=$ Pakan basal $+2 \%$ kunyit dari jumlah konsumsi pakan

$\mathrm{T}_{2}=$ Pakan basal $+2 \%$ kunyit dari jumlah konsumsi air minum

Tabel 1. Kandungan Nutrien Pakan Crumble BP 11

\begin{tabular}{lc}
\hline Zat nutrien & $(\%)^{*}$ \\
\hline Kadar air & 13,0 \\
Protein & $21,0-23,0$ \\
Lemak & 5,0 \\
Serat & 5,0 \\
Abu & 7,0 \\
Kalsium & 0,9 \\
Posfor & 0,6 \\
\hline
\end{tabular}

* Hasil analisis PT. Charoen Pokphand Indonesia

\section{Metode}

Parameter yang diamati pada penelitian ini yaitu konsumsi pakan, konsumsi air minum, pertambahan bobot badan, bobot badan akhir, konversi pakan, mortalitas dan Income over feed and chick cost. Pemeliharaan dilakukan selama 30 hari. Penimbangan sampel DOC dilakukan sesaat setelah ayam tiba untuk mengetahui bobot awal ayam penelitian. Setelah berumur 12 hari, ayam broiler kemudian disekat sesuai dengan perlakuan dan ulangan yang telah ditentukan. Pakan perlakuan diberikan pada hari ke-13. Ayam broiler dibagi berdasarkan unit percobaan secara acak. Setiap hari pemberian serta sisa pakan dan air minum diukur untuk mengetahui konsumsi pakan dan air minum. Penghitungan jumlah ayam dilakukan untuk mengetahui tingkat mortalitas ayam penelitian. Setiap pekan dilakukan penimbangan ayam untuk mengetahui pertambahan bobot badan. Konversi pakan diukur dengan rumus :

$$
\begin{aligned}
& =\frac{\text { Konsumsi pakan }}{\text { Pertambahan berat badan }} \\
& \text { Setelah hari ke } 30 \text { pemeliharaan }
\end{aligned}
$$
ayam broiler dipanen. Proses pemanenan dilakukan dengan menimbang bobot akhir ayam broiler. Income over feed and chick cost dihitung dengan menggunakan rumus: Income over feed and chick cost (Rp) $=(\mathrm{BB}$ akhir $\mathrm{x}$ harga/ $\mathrm{kg}$ bobot hidup $)-$ ((Konsumsi pakan $\mathrm{x}$ harga/kg pakan)+ harga DOC).

\section{Analisis Data}

Data yang diperoleh diuji dengan sidik ragam (ANOVA) dengan bantuan software SPSS Ver. 16,0. Jika perlakuan memperlihatkan pengaruh nyata, maka dilanjutkan dengan uji wilayah berganda (Duncan) untuk mengetahui perbedaan antara perlakuan (Gasperz, 1994).

\section{HASIL DAN PEMBAHASAN}

Pemberian pakan mengandung herbal kunyit tidak berpengaruh nyata $(P>0,05)$ terhadap performa ayam broiler strain cobb. (Tabel 2). Parameter performa yang terdiri dari konsumsi pakan kumulatif, konsumsi air minum kumulatif, pertambahan bobot badan, bobot badan akhir, konversi pakan dan mortalitas tidak dipengaruhi $(\mathrm{P}>0,05)$ oleh penambahan kunyit baik melalui pakan maupun melalui air minum. 
Tabel 2. Performa Ayam Broiler Strain Cobb yang Diberi Pakan Mengandung Herbal Kunyit.

\begin{tabular}{lccc}
\hline \multirow{2}{*}{ Parameter } & \multicolumn{3}{c}{ Perlakuan } \\
\cline { 2 - 4 } & T0 & T1 & $2,01 \pm 0,06$ \\
Konsumsi pakan kumulatif (kg/ekor) & $1,94 \pm 0,05$ & $1,96 \pm 0,10$ & $6,84 \pm 0,08$ \\
Konsumsi air minum kumulatif (l/ekor) & $6,93 \pm 0,28$ & $7,33 \pm 0,32$ & $1,65 \pm 0,09$ \\
Pertambahan bobot badan (kg/ekor) & $1,58 \pm 0,25$ & $1,52 \pm 0,14$ & $1,70 \pm 0,09$ \\
Bobot akhir (kg/ekor) & $1,63 \pm 0,25$ & $1,56 \pm 0,14$ & $1,22 \pm 0,10$ \\
Konversi pakan & $1,25 \pm 0,21$ & $1,30 \pm 0,12$ & $0,00 \pm 0,00$ \\
Mortalitas (\%) & $6,25 \pm 12,50$ & $9,375 \pm 11,97$ & 11.582 \\
Income over feed and chick cost (Rp/ekor)
\end{tabular}

Keterangan : ${ }^{\text {) }}$ tidak dianalisis secara statistik

Nilai konsumsi pakan pada penelitian ini yaitu berkisar antara 1,94 2,01 kg/ekor sehingga menghasilkan Income over feed and chick cost yang tinggi. Konsumsi pakan pada penelitian ini lebih rendah dibandingkan dengan penelitian yang dilakukan (Ulupi et al., 2015) yang menyatakan bahwa konsumsi pakan ayam broiler yang diberikan serbuk pinang yaitu pada kisaran $2,3 \mathrm{~kg} / \mathrm{ekor}$ dengan Income over feed and chick cost pada kisaran Rp 5685- 7080. Konsumsi pakan akan mengakibatkan tingginya konsumsi nutrien yang tinggi yang berkontribusi pada peningkatan pertumbuhan ayam pedaging (Widiawati, et al., 2018). Konsumsi pakan yang tinggi akan meningkatkan pertambahan bobot badan yang akan memberikan konversi yang rendah dan pada akhirnya memberikan keuntungan yang tinggi pada peternak.

Secara statistik memang tidak memperlihatkan pengaruh yang nyata, namun jika diperhatikan secara angka perlakuan T2 menunjukkan performa ayam yang tinggi. Konsumsi pakan tertinggi pada perlakuan T2, sehingga secara otomatis pertambahan bobot badan juga tertinggi pada perlakuan T2. T2 adalah perlakuan dengan pemberian kunyit melalui air minum taraf $2 \%$. Minyak atsiri pada kunyit dapat mempercepat pengosongan isi lambung
(Adi, 2009). Pengosongan isi lambung secara cepat akan merangsang ayam untuk mengkonsumsi pakan lebih banyak sehingga akan meningkatkan kapasitas pencernaan.

Bobot badan akhir yang tinggi pada perlakuan T2 akibat penambahan kunyit melalui air minum. Penambahan kunyit melalui air minum secara cepat terabsorpsi oleh saluran pencernaan sehingga akan meningkatkan fungsi organ pencernaan. Pujianti et al. (2013) menyatakan bahwa fungsi kunyit untuk meningkatkan kerja organ pencernaan unggas adalah merangsang dinding kantong empedu mengeluarkan cairan empedu dan merangsang keluarnya getah pankreas yang mengandung enzim amilase, lipase, dan protease yang berguna untuk meningkatkan pencernaan bahan pakan seperti karbohidrat, lemak, dan protein.

Bobot badan akhir yang tinggi pada perlakuan T2 menyebabkan nilai konversi pakan lebih baik yang ditunjukkan dengan nilai yang rendah. Hal tersebut menggambarkan bahwa penggunaan pakan lebih optimal pada perlakuan T2 untuk pembentukan daging. Berdasarkan penelitian ini memperlihatkan keterikatan antara fungsi dari kunyit terhadap proses konsumsi dan konversi pakan ayam broiler yang berpengaruh dalam pembentukan daging serta dapat menghasilkan 
pertambahan berat badan ayam broiler yang optimal (Bintang \& Nataamijaya, 2005).

Walaupun semua parameter performa tidak berpengaruh secara statistik namun Perlakuan T2 menghasilkan tingkat mortalitas $0 \%$ atau dengan kata lain tidak ada satupun ayam penelitian pada perlakuan T2 yang mengalami kematian. Hal ini membuktikan bahwa kunyit memberikan efek yang sangat positif terhadap kesehatan ayam. Kunyit memiliki keunggulan mampu memperbaiki pencernaan ayam, membantu memperbaiki jaringan tubuh dan menjaga daya tahan tubuh ayam. Senyawa yang terkandung dalam tanaman kunyit adalah senyawa Curcuminoid yang mempunyai kegunaan sebagai antioksidan (Iwan, 2002), dan minyak atsiri yang bersifat sebagai pemusnah bakteri dan mengandung sifat antiinflamasi atau antiradang (Kristio, 2007).

Berdasarkan perhitungan nilai Income over feed and chick cost maka terlihat bahwa perlakuan T2 memberikan keuntungan yang paling besar yaitu Rp 11.582,-Sehingga jika diaplikasikan pada peternakan ayam broiler tentu saja menghasilkan keuntungan yang sangat signifikan. Nilai income over feed and chick cost adalah gambaran keuntungan, yang merupakan selisih antara nilai penjualan ayam broiler saat panen dengan biaya pakan dan anak ayam (Ulupi et al., 2015).

\section{KESIMPULAN}

Pemberian kunyit pada ayam broiler strain cobb lebih optimal jika diaplikasikan melalui air minum dengan taraf $2 \%$.

\section{DAFTAR PUSTAKA}

Adi, R. (2009). Efektifivitas Betain Pada
Pakan Ayam Broiler Rendah Metionin Berdasarkan Parameter Berat Badan dan Karkas. Solo. Fakultas Pertanian Universitas Sebelas Maret.

Bintang, \& Nataamijaya, A. G. (2005). Pengaruh Penambahan Tepung Kunyit (Curcuma domestica) dalam Ransum Broiler. Bogor. Balai Penelitian Ternak.

Castanon, J. I. R. (2007). History of the use of antibiotic as growth promoters in European poultry feeds. Poultry Science, 86(11):2466-2471.

Gasperz, V. (1994). Metode Rancangan Percobaan. Bandung: CV. Armico.

Marlina A, N., Zubaidah, E., \& Sutrisno, A. (2015). Pengaruh pemberian antibiotika saat budidaya terhadap keberadaan residu pada daging dan hati ayam pedaging dari peternakan rakyat. Jurnal Ilmu-Ilmu Peternakan, 25(2):10-19.

Pujianti, N. A., Jaelani, A., \& Widaningsih, N. (2013). Penambahan tepung daun kunyit (Curcuma domestica) dalam ransum terhadap daya cerna protein dan bahan kering pada ayam pedaging. ZIRAA'AH. 36(1):49-59.

Sinurat, A. P., Purwadaria, T., Togatorop, M. H., \& Pasaribu, T. (2003). Pemanfaatan bioaktif tanaman sebagai "feed additive" pada ternak unggas: pengaruh pemberian gel lidah buaya atau ekstraknya dalam ransum terhadap penampilan ayam pedaging. Jurnal Ilmu Ternak Dan Veteriner. 8(3):139-145.

Ulupi, N., Soesanto, I. R. H., \& Inayah, S. K. (2015). Performa Ayam Broiler dengan Pemberian Serbuk Pinang sebagai Feed Aditive. Jurnal Ilmu Produksi Dan Teknologi Hasil Peternakan. 03(1):8-11.

Widiawati, J., Muharlien, \& Sjofjan, O. (2018). Effek Penggunaan Probiotik dan Tepung Kunyit (Curcuma domestica Val.) pada Pakan Terhadap 
Performa Broiler. TERNAK TROPIKA

Journal of Tropical Animal

Production. 19(2):105-110. 